\title{
Diagnostic Availability of Estrogen Receptor Alpha mRNA on Cervical Cancer Tissue
}

\author{
Geehyuk Kim ${ }^{1}$, Kwangmin Yu ${ }^{1}$, Jungho Kim ${ }^{1}$, Seoyong Kim ${ }^{1}$, Sunyoung Park ${ }^{1}$, Sungwoo Ahn ${ }^{1}$, \\ Ji-Young Lee ${ }^{1}$, Sunghyun Kim² ${ }^{2}$, Ho-Hyun Park ${ }^{3}$, Dongsup Lee ${ }^{4}$
}

${ }^{1}$ Department of Biomedical Laboratory Science, College of Health Sciences, Yonsei University, Wonju, Korea

${ }^{2}$ Department of Clinical Laboratory Science, College of Health Sciences, Catholic University of Pusan, Pusan, Korea

${ }^{3}$ Department of Biomedical Laboratory Science, Mokpo Science University, Mokpo, Korea

${ }^{4}$ Department of Clinical Laboratory Science, Hyejeon College, Hongseong, Korea

\section{자궁경부암 조직에서 에스트로겐 수용체 알파 mRNA의 진단적 유용성}

\author{
김지혁 ${ }^{1}$, 유광민 ${ }^{1}$, 김정호 ${ }^{1}$, 김서용 ${ }^{1}$, 박선영 $^{1}$, 안성우 $^{1}$, 이지영 ${ }^{1}$, 김성현 $^{2}$, 박호현 ${ }^{3}$, 이동섭 ${ }^{4}$ \\ ${ }^{1}$ 연세대학교 임상병리학과, ${ }^{2}$ 부산가톨릭대학교 임상병리학과, ${ }^{3}$ 목포과학대학교 임상병리과, ${ }^{4}$ 혜전대학교 임상병리과
}

\begin{abstract}
Cervical cancer is the fourth most frequently diagnosed cancer in women worldwide. In lower Human Development Index countries, it has the second highest incidence and mortality among cancer in women. Therefore, better diagnosis and treatment systems are needed. Among them, estrogen receptor alpha (ER- $\alpha$ ) mRNA expression has been analyzed with RT-qPCR since several studies reported that ER- $\alpha$ is necessary in the maturation of the uterus and is related to cervical cancer. In this study, ER- $\alpha$ quantitative analysis was performed on various lesions and normal tissue samples. Based on the receiver operating characteristic (ROC) curve, its sensitivity and specificity were $85 \%$ and $75 \%$, respectively, showing higher or similar results to those of conventional HPV tests. In addition, its expression level was analyzed with clinical information. With regression analysis, the $R$ square value between the ER- $\alpha$ mRNA expression level and menopause status was 0.5041 , indicating a strong correlation. This study was performed as part of a pilot study and suggests that $E R-\alpha$ is related to carcinogenesis. Future studies will examine other hormones and menopausal factors with a larger sample size.
\end{abstract}

Key words: Age, Cervical cancer, Estrogen receptor alpha, Formalin-fixed paraffin-embedded tissue, Menopause

\section{This is an Open Access article distributed under the terms of the Creative Commons Attribution Non-Commercial Licens (http://creativecommons.org/licenses/by-nc/4.0) which permits unrestricted non-commercial use, distribution, and reproduction in any medium, provided the original work is properly cited.}

Copyright $@ 2018$ The Korean Society for Clinical Laboratory Science. All rights reserved.
Corresponding author: Dongsup Lee Department of Clinical Laboratory Science, Hyejeon College, 25 Daehak-gil, Hongseong 32244, Korea

Tel: 82-41-630-5342

Fax: 82-41-630-5364

E-mail: eastern3547@naver.com

Received: October 11, 2018

Revised $1^{\text {st. }}$ November 7, 2018 Revised 2nd: November 9, 2018

Revised $3^{\text {rd: }}$ : November 14,2018 Accepted: November 14, 2018

\section{INTRODUCTION}

Cervical cancer ranks as the fourth most frequently diagnosed cancer with an estimated 570,000 cases in women worldwide [1]. And it also ranks as the fourth cancer leading death with an estimated 311,000 deaths in women worldwide. However, in lower human development index (HDI) countries, it shows the second most incidence and mortality among the women cancer. Therefore, the better diagnosing and treatment systems 
are urgently needed. Since human papillomavirus (HPV) is most pivotal cause of cervical cancer, HPV test is generally performed to diagnose cervical cancer with cytological and histological examination [2-4]. Recently, European Society for Medical Oncology and European Cancer Congress issued a guideline recommending HPV test alone as a primary screening test in 2015 [5]. However, several studies have confirmed the association between cervical cancer and hormone, especially estradiol (E2) [6-8]. Sufficient estrogen induces sexual maturation and ovulation to mouse. However, continuous estrogen promotes cervical carcinogenesis regardless of HPV transgenic mouse or not [9-13]. Moreover, some studies show dramatic differences estrogen receptor (ER) expression between cancer and normal [14].

Those results indicate estrogen conditions could be essential to promote cancer and affect risk of cervical cancer more than HPV. A similar example can be found in human. The premenopausal women affected by estrogenic stimulation continuously like oral contraceptives or consequence of pregnancy [15, 16]. Actually, several clinical studies conducted on human shows HPV negative patient could develop into cancer [17-19]. And their estrogen related markers such as Ki-67 and p16 expressed relatively higher than normal [20]. Among them, studies related to estrogen receptor- $\alpha$ (ER- $\alpha)$ were the most common in particular [21-24]. Therefore, our study group analyzed relation between ER- $\alpha$ and cervical cancer carcinogenesis quantitatively. We also conducted with pre-cancer group to certify ER- $\alpha$ as prognosis marker. And the results were analyzed by age of the patients. Cervical cancer occurs most commonly among women in their 40s and 50s [25-28]. It is generally explained by the hypothesis that HPV has developed into cancer by persistent infection [29]. On the other hand, the 40s and 50s are hormone imbalance periods such as the menopause. This fact also suggests the relation between hormone and cancer occurrence. Thus, our research group analyzed ER- $\alpha$ expression and age with patient sample and evaluated its clinical significance.

\section{MATERIALS AND METHODS}

\section{Study subjects}

\section{1) Histological samples}

The samples were collected from cervical cancer patients and healthy subjects at Wonju Severance Christian Hospital, Wonju, Republic of Korea, from January 2010 to December 2014. All subjects provided clinical information and this study was approved by the Institutional Ethics Committee of Yonsei University Wonju College of Medicine (approval no. YWMR-12-4-010). The study subjects were formalin fixed paraffin embedded (FFPE) cervical cancer tissue samples, those were composed of 20 squamous cell carcinoma (SCC), 20 cervical intraepithelial neoplasia grade 3 (CIN3), 20 CIN1, and 20 normal subjects (Table 1). The subjects' age ranged from 26 to 79 years, and the median age was 48 years old.

\section{2) Deparaffinization of FFPE tissue and total RNA extraction}

Three pieces of 10- $\mu$ m-thick sections of cervical FFPE tissues were used for total RNA extraction. Qiagen RNeasy FFPE kits (Qiagen, Hilden, Germany) were used according to the manufacturer's protocol. To remove paraffin from FFPE samples, a $160 \mu \mathrm{L}$ deparaffinization solution was added. After shaking and vortexing, the tube was heated for $3 \mathrm{~min}$ at $56^{\circ} \mathrm{C}$ for the paraffin to be melted. After centrifugation, $150 \mu \mathrm{L}$ proteinase $\mathrm{K}$ digestion buffer (PKD) was added and mixed by vortexing. The tube was centrifuged at 11,000 $\times \mathrm{g}$ for $1 \mathrm{~min}$ at room temperature. After that, $10 \mu \mathrm{L}$ proteinase $\mathrm{K}$ was added to the lower, clear phase, which was incubated at $56^{\circ} \mathrm{C}$ for $15 \mathrm{~min}$, then at $80^{\circ} \mathrm{C}$ for $15 \mathrm{~min}$. The lower, uncolored phase is

Table 1. Clinical information of histological samples

\begin{tabular}{ccc}
\hline Histological diagnosis & Age (mean) & No. of samples \\
\hline SCC & $35 \sim 79(57.1)$ & 20 \\
CIN3 & $29 \sim 64(46.0)$ & 20 \\
CIN1 & $26 \sim 69(45.5)$ & 20 \\
Normal & $35 \sim 76(48.2)$ & 20 \\
Total & $26 \sim 79(49.2)$ & 80 \\
\hline
\end{tabular}

Abbreviations: SCC, squamous cell carcinoma; CIN, cervical intraepithelial neoplasia. 
transferred into a new $2 \mathrm{~mL}$ micro-centrifuge tube, which was centrifuged for $15 \mathrm{~min}$ at $20,000 \times \mathrm{g}$ at room temperature. The supernatant was transferred to a new microcentrifuge tube taking care not to disturb the pellet. After adding $16 \mu \mathrm{L}$ DNase booster buffer and $10 \mu \mathrm{L}$ DNase I solution, it was inverted and centrifuged briefly. Through incubating at room temperature for $15 \mathrm{~min}, 320 \mu \mathrm{LBC}$ buffer and $720 \mu \mathrm{L} 100 \%$ ethanol were added to the sample. Then, the sample was transferred to RNeasy minelute spin column and centrifuged for 15 seconds at 8,000 $\times \mathrm{g}$. The flow-through was discarded. After adding $500 \mu \mathrm{L}$ buffer RPE, the tube with column was centrifuged for $2 \mathrm{~min}$ at $8,000 \times \mathrm{g}$ to wash the spin column membrane and the flow-through was discarded. Then, RNeasy MinElute spin column was placed to new $2 \mathrm{~mL}$ collection tube. After adding $15 \mu \mathrm{L}$ RNase-free water directly to the spin column membrane. The tube was centrifuged for $1 \mathrm{~min}$ at full speed to elute the RNA. The purity and concentration of the total RNA were determined by measuring the absorbance ratio at 260 and $280 \mathrm{~nm}$ using a spectrophotometer (Infinite 200, Tecan, Salzburg, Austria). All preparation and handling procedures were conducted under RNase-free conditions. The isolated total RNA was stored at $-70^{\circ} \mathrm{C}$ until used.

\section{3) cDNA synthesis}

By using M-MLV reverse transcriptase kits (Invitrogen, Carlsbad, CA, USA) and random hexamers (Invitrogen, Carlsbad, CA, USA), complementary DNA (CDNA) was synthesized according to the manufacturer's recommendation. In short, $10 \mu \mathrm{L}$ of total RNA was added to a mixture containing $1 \mu \mathrm{L}$ of $10 \mathrm{mM}$ dNTP mix at neutral $\mathrm{pH}, 1 \mu \mathrm{L}$ of $0.25 \mu \mathrm{g} / \mu \mathrm{L}$ random hexamers, and $5 \mu \mathrm{L}$ of DEPC-treated water. The PCR mixures were incubated at $65^{\circ} \mathrm{C}$ for $5 \mathrm{~min}$ and chilled on ice. After adding a mixture of $4 \mu \mathrm{L}$ of first-strand buffer ( $5 \times$ ), $2 \mu \mathrm{L}$ of $0.1 \mathrm{M}$ dithiothreitol (DTT), and $1 \mu \mathrm{L}$ of $\mathrm{M}$-MLV reverse transcriptase (at room temperature), cDNA synthesis was performed at $25^{\circ} \mathrm{C}$ for $10 \mathrm{~min}, 37^{\circ} \mathrm{C}$ for $50 \mathrm{~min}$, and $70^{\circ} \mathrm{C}$ for $15 \mathrm{~min}$. The cDNA was stored at $-70^{\circ} \mathrm{C}$ until used.

\section{4) Histopathological diagnosis}

The histopathological diagnosis was classified as normal, cervical intraepithelial neoplasia 1 (CIN 1), cervical intraepithelial neoplasia 2 (CIN 2), cervical intraepithelial neoplasia 3 (CIN 3), adenocarcinoma (ADC), and squamous cell carcinoma (SCC). CIN1 is the least risky type and represents only mild dysplasia or abnormal cell growth. It is confined to basal $1 / 3$ of the epithelium. This usually corresponds to HPV infection, though it can take several years to clear. CIN 2 is moderate dysplasia confined to the basal $2 / 3$ of the epithelium. CIN 3 is severe dysplasia that spans more than $2 / 3$ of the epithelium and may involve the full thickness. This lesion may sometimes also be referred to as cervical carcinoma in situ.

\section{5) RT-qPCR TaqMan assays of ER- $\alpha$ mRNA}

The ER- $\alpha$ mRNA expression was detected by RT-qPCR quantitatively. RT-qPCR was performed in a final volume of $20 \mu \mathrm{L}$, containing $10 \mu \mathrm{L}$ of $2 \times$ Thunderbird probe $\mathrm{qPCR}$ mix (Toyobo, Osaka, Japan), $5 \mu \mathrm{L}$ of primer, $5 \mu \mathrm{L}$ of template cDNA, $2 \mu \mathrm{L}$ of distilled water, and $3 \mu \mathrm{L}$ of TaqMan probe mixture. TaqMan probe mixture is composed with 1 $\mu \mathrm{L}$ of each primer (10 pmol), and $1 \mu \mathrm{L}$ of probe (10 pmol). The primers and probe were designed using the $A B I$ Primer Express 3.0 Software (Applied Biosystems, Foster City, CA, USA) and Primer-BLAST (NCBI; National Center for Biotechnology Information, Bethesda, MD, USA). The sequences of the primers used were 5'-GTGCCAGGCTTTGTGGATTT- $3^{\prime}$ and 5'-GATCTCTAGCCAGGCACATTCT- 3 ' for ER- $\alpha$ and 5'-FAM-ACCCTCCATGATCAGGTCCACCTT-BHQ1-3' for the probe.

The positive and negative controls were included in every procedure with the samples simultaneously. The conditions of PCR were $3 \mathrm{~min}$ at $95^{\circ} \mathrm{C}$, followed by 50 cycles of $3 \mathrm{~min}$ at $95^{\circ} \mathrm{C}$ for $3 \mathrm{sec}$ and at $60^{\circ} \mathrm{C}$ for $30 \mathrm{sec}$ using a CFX-96 real-time PCR system (Bio-Rad, Hercules, CA, USA).

It is very difficult to extract a high quality of RNA from clinical specimens such as FFPE tissues. And relative mRNA levels need to be determined based on the reference housekeeping genes. Thus, to determine RNA 
quality and avoid false negatives, glyceraldehyde-3phosphate dehydrogenase (GAPDH) was used as an internal control.

In order to confirm how the levels of ER- $\alpha$ were expressed, FFPE cervical cancer tissues and noncancerous FFPE normal tissues were performed by RT-qPCR. The gene expression was calculated using the delta $\mathrm{Ct}(\Delta \mathrm{Ct})$.

\section{$\Delta \mathrm{Ct}=[\Delta \mathrm{Ct}$, Target $(\mathrm{Ct}$ target gene-Ct housekeeping gene]}

Relative gene expression was assessed using the comparative Ct method ( $\triangle \Delta$ Ct method) [30]. The amount of target, normalized to an internal housekeeping gene, GAPDH, and relative to a calibrator, is given by 2- $\triangle \Delta \mathrm{Ct}$ which was the normalized according to the following equation:

\section{$\Delta \Delta \mathrm{Ct}=[\Delta \mathrm{Ct}$, Target (Ct target gene-Ct housekeeping} gene on target sample)- $\Delta \mathrm{Ct}$, Control (Ct target gene-Ct housekeeping gene on reference sample)].

Then, data were calculated the expression ratio by 2$\triangle \triangle \mathrm{Ct}$ that represents gene expression.

\section{6) Statistical analysis}

Statistical analysis was conducted using GraphPad Prism software (Version 5.02, La Jolla, CA, USA) and Statistical Package for the Social Sciences (SPSS) software v18.0 (SPSS Inc., Chicago, IL, USA).

The Kolmogorov-Smirnov test and Shapiro-Wilk test were used to determine whether or not characteristic of data was parametric. A Student's t-test and Mann-Whitney U test were used to determine the statistical significance as parametric and non-parametric statistics, respectively. To apprehend the relationship between variables, Spearman's rho and Kendall's tau-b were used for the correlation analysis. Furthermore, to estimate the result, simple linear regression and multiple linear regression were used for conducting the regression analysis. For all tests, $P<0.05$ was considered statistically significant. The differences were considered statistically significant when ${ }^{*} P<0.05$,
${ }^{* *} P<0.01$, or ${ }^{* * * *} P<0.001$. The cut-off value for distinguishing between positive and negative results is determined from the receiver operating characteristic (ROC) curve.

\section{RESULTS}

\section{Distribution of relative expression of $E R-\alpha m R N A$ in normal and cancer group}

The relative expressions of ER- $\alpha$ mRNA were detected with RT-qPCR in normal and cancer group. As shown in Figure 1, normal and cancer group was distinguished by ER- $\alpha$ gene expression showing a statistically significant difference $(P<0.05)$. In order to determine the optimal cut-off value for clinical use, ROC curve analysis was also performed. The area under the curve (AUC) obtained using samples was 0.7588 . The cut-off value was determined by the likelihood ratio. The highest likelihood ratio was a relative gene expression over 0.66 that had the highest sensitivity and specificity.

\section{ER- $\alpha$ gene expressions analysis according to the lesions with histologic samples}

ER- $\alpha$ gene expression of each lesion was compared to that of normal group. The normal and CIN3 group
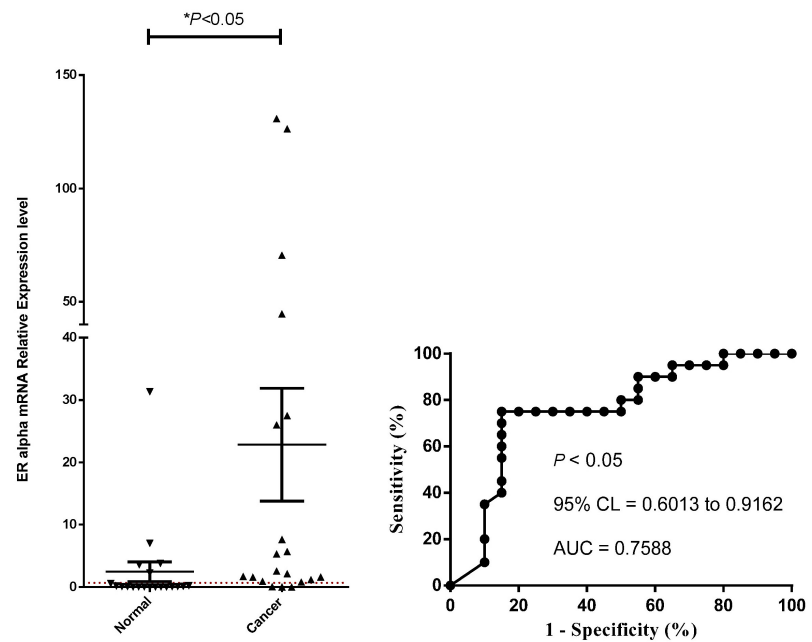

Figure 1. Relative distribution of ER- $\alpha$ mRNA expression in normal and cancer group. The gene expressions of ER- $\alpha$ were analyzed in normal and cancer groups by RT-qPCR. 
compared to cancer group showed $P<0.05$, respectively (Figure 2). As previously mentioned, the gene expressions greater than 0.66 were determined as positive. The positive rate of normal, CIN1, CIN3, and cancer group shows 25.0, 55.0, 40.0, and 85.0, respectively (Table 2). The normal and CIN3 group discriminated from cancer

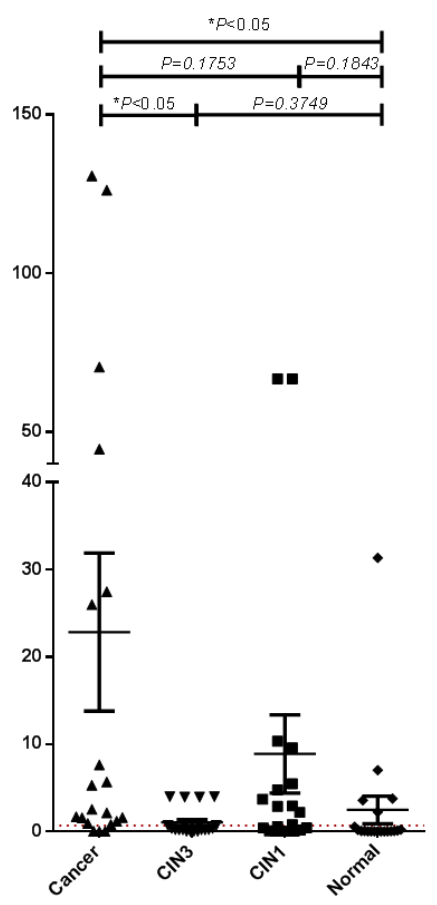

Figure 2. ER- $\alpha$ gene expression distribution according to the lesions. The ER- $\alpha$ gene expressions in each lesion are detected. The normal and CIN3 group compared to cancer group showed $P<0.05$, respectively.

(A)

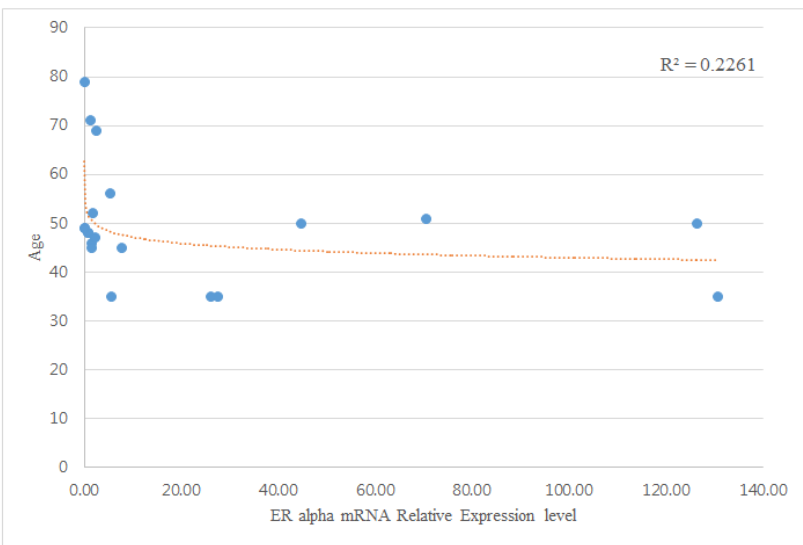

group statistically showing $P<0.05$.

\section{Age-dependent ER- $\alpha$ expression with histologic samples}

The correlation between ER- $\alpha$ expression and age was examined with regression analysis ( $\mathrm{R}$-squared, $\mathrm{R}^{2}$ ). The analysis was conducted in normal and cancer group. As shown in Figure 3A, $\mathrm{R}^{2}$ value of cancer was 0.2261 while that of normal was 0.0019 . To examine the correlation between menopause status and ER- $\alpha$ expression, premenopausal patient and post-menopausal patient are categorized to ' 0 ' and ' 1 '. Its $\mathrm{R}^{2}$ value is 0.5041 (Figure 3B).

Table 2. Comparison of ER- $\alpha$ mRNA RT-qPCR results with histological diagnosis

\begin{tabular}{lcc}
\hline \multirow{2}{*}{ Groups } & \multicolumn{2}{c}{ ER- $\alpha$ mRNA RT-qPCR } \\
\cline { 2 - 3 } & Positives* & Negatives \\
\hline Cancer patients & $15(85.0)$ & $5(25.0)$ \\
CIN3 patients & $8(40.0)$ & $12(60.0)$ \\
CIN1 patients & $11(55.0)$ & $9(45.0)$ \\
Normal subjects & $5(25.0)$ & $15(75.0)$ \\
Total & 39 & 41 \\
\hline
\end{tabular}

Values are presented as $\mathrm{N}(\%)$.

*The positive rates of cervical cancer and normal groups were calculated based on cut-off of ER- $\alpha$ mRNA levels.

Abbreviations: ER- $\alpha$, estrogen receptor alpha; CIN, cervical intraepithelial neoplasia.

(B)

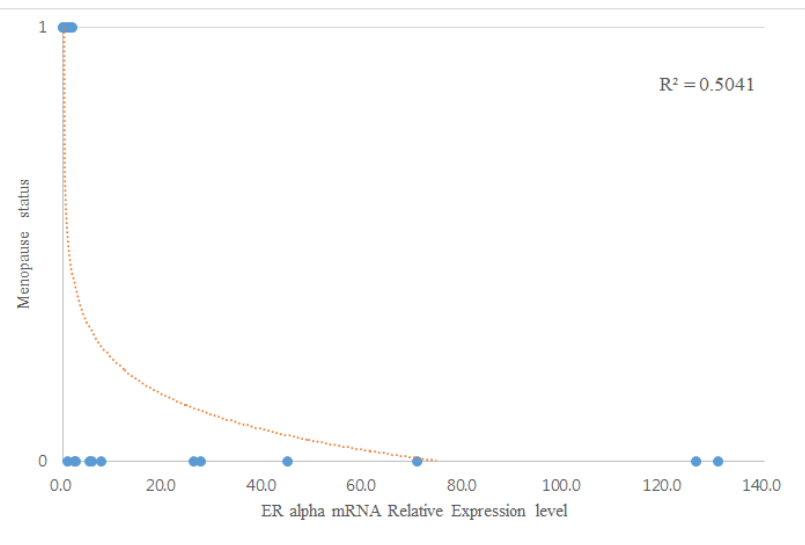

Figure 3. ER- $\alpha$ gene expression in cancer group. The gene expression analysis was performed using regression analysis in cancer group. (A) It was performed between ER- $\alpha$ expression and patient ages. The $R^{2}$ value of cervical cancer was 0.2261 (B) It was performed between ER- $\alpha$ expression and menopause status. The menopause status 0 and 1 stands for pre-menopausal patient and post-menopausal patient, respectively. The $R^{2}$ value of cervical cancer was 0.5041 . 


\section{DISCUSSION}

The study was investigated to understand the relevance between cervical cancer and hormone. Especially, relative expression of ER- $\alpha$ was analyzed among the biomarkers related to the inflow of estrogen. In fact, there are a number of articles about ER- $\alpha$ with clinical samples [31, 32]. However, this study was performed with quantitative analysis. And FFPE tissue was used in this study while cervical exfoliated cell is used for the study commonly. In case of cytology sample, normal sample could be brought into cancer sample in process of extraction [33]. Whereas FFPE tissue prevents normal sample flowing freely to the cancer samples through microscopic inspection and immunohistochemistry staining assay differentiating the normal tissue and cancer tissue correctly. Based on the ROC curve, positive rate of normal and cancer tissues was $25 \%$ and $85 \%$ respectively. Also, it interpreted specificity of $75 \%$ and sensitivity of $85 \%$. While the specificity was similar to existing diagnostic marker of cervical cancer, the sensitivity was much higher [34, 35]. And the HPV-negative sample in cancer tissue was shown as the positive result in ER- $\alpha$ implying HPV-related marker and ER- $\alpha$ marker could diagnose cervical cancer complementarily. And the relative risk was analyzed to investigate the effect of ER- $\alpha$ on the cervical cancer occurrence. The odds ratio was 17, the higher value than that of HPV E6/E7 (13.4).

To analyze expression levels depends on lesion severity, relative expression was also analyzed in CIN1 and CIN3, precancerous stage. The positive rate was estimated to 55\% and 40\%, respectively. With regression analysis, $\mathrm{R}$ square was estimated as 0.062 .

As mentioned in introduction, the study has analyzed the relevance between age and relative expression. Many articles and researcher explain why the cervical cancer occurrence is the highest in forty and fifty by persistent infection of HPV [36-38]. Considering that most of cervical cancer patients are of the forties and fifties regardless of standards in health and vaccine policy, another point of view is necessary [25-28]. The researcher also noted the average age of menopausal Korean women was 49.7 years old [39]. This period is hormonally unbalanced, so it could affect cancer occurrence. So, at first, regression analysis was performed between the relative expression of ER- $\alpha$ and age. Its R square value was 0.2261 in cancer group. In addition, the analysis was also performed in normal group to examine the association of ER- $\alpha$ in normal subject and its value was 0.0019. This time, instead of numerical statistics analysis, categorical statistics analysis by menopause status was applied. R square value was 0.5041 in cancer patient and 0.0361 in normal group, respectively. In general, $\mathrm{R}$ square value greater than 0.5 is statistically significant [40-42]. In sum, these results suggest ER- $\alpha$ could affect carcinogenesis strongly related with menopause status. Therefore, this study show ER- $\alpha$ is involved in the development of cancer with clinical tissue samples and it is necessary to study with menopause status.

This result has been conflicting. Some studies reported the number or expression of ER- $\alpha$ markers decreases and disappears in cervical cancer [14, 43] However, these reports did not consider subject's age and menstruation condition. Those things considered, another consequence could be drawn.

The hormone including ER- $\alpha$ would have strong connection with cervical cancer carcinogenesis especially adenocarcinoma or adeno-squamous carcinoma; adenocarcinoma is originated from organ producing hormone $[4,44]$. Moreover, the portion of adenocarcinoma in cervical cancer is getting higher [46, 47]. Therefore, ER-based diagnostics applying to adeno-squamous carcinoma and adenocarcinoma is also rational.

This study was performed as part of the pilot study because ER- $\alpha$ mRNA expression hasn't be analyzed quantitatively with clinical tissue sample before. Further study would be conducted with increasing the number of samples. And it will cover other hormone and menopausal factor. 


\section{요 약}

자궁경부암은 세계적으로 여성에서 네번째로 많이 진단되는 암이다. 개발 지수가 낮은 개발도상국이나 후진국에서는 자궁 경부암의 발생률과 사망률이 훨씬 심각하다. 따라서 더 나은 진 단법과 치료법이 시급하다. 인유두종바이러스가 자궁경부암 발생의 주요 원인으로 알려진 이후로 바이러스에 대한 검사가 세포검사·조직검사와 함께 자궁경부암을 진단하는데 일상적 으로 쓰이고 있다. 하지만, HPV 검사에서 음성을 보이는 환자가 자궁경부암으로 발전하는 사례가 계속해서 발견되고 있다. 본 연구에서는 HPV 외에 자궁경부암의 원인으로 생각되는 인자 들에 대해 분석하였다. 그 중에서도 에스트로겐 수용체 알파의 $\mathrm{mRNA}$ 발현양을 실시간 역전사 중합효소 연쇄반응을 통해 분 석하였다. 에스트로겐 수용체 알파에 대해서는 예전부터 자궁 내막을 성숙시키면서 동시에 자궁경부암의 발암 기전에 연관이 있을 것이라는 추측이 있었는데, 본 연구에서는 이에 대해 임상 검체를 통해 양적 분석을 진행하였다. ROC 곡선을 바탕으로, $85 \%$ 의 민감도와 $75 \%$ 의 특이도를 확인할 수 있었는데, 이 값은 기존의 HPV 검사법보다 유사하거나 더 높은 값이었다. 나이, 병 변의 심한 정도 등을 포함한 임상 정보를 바탕으로 회귀 분석한 결과 폐경 여부와 에스트로겐 수용체 알파의 발현양이 높은 연 관성을 확인하였다. 본 연구는 예비 연구의 일종으로, 추후 연구 에서 가능성이 확인된 호르몬과 폐경에 관련된 유전자를 대상 으로 더 많은 검체로 분석해야 할 것이다.

Acknowledgements: This work was supported by Hyejeon College grant.

\section{Conflict of interest: None}

Author's information (Position): Kim $G^{1}$, Graduate student; Yu K${ }^{1}$, Graduate student; Kim $\mathrm{J}^{1}$, Graduate student; Kim $S^{1}$, Graduate student; Park $S^{1}$, Graduate student; Ahn $S^{1}$, Graduate student; Lee $\mathrm{JY}^{1}$, Graduate student; Kim $\mathrm{S}^{2}$, Professor; Park $\mathrm{HH}^{3}$, Professor; Lee $\mathrm{D}^{4}$, Professor.

\section{REFERENCES}

1. Bray F, Ferlay J, Soerjomataram I, Siegel RL, Torre LA, Jemal A. Global cancer statistics 2018: GLOBOCAN estimates of incidence and mortality worldwide for 36 cancers in 185 countries. CA Cancer J Clin. 2018;0:1-31.

2. Walboomers JM, Jacobs MV, Manos MM, Bosch FX, Kummer JA, Shah KV, et al. Human papillomavirus is a necessary cause of invasive cervical cancer worldwide. J Pathol. 1999;189:12-19.

3. Franco EL, Duarte-Franco E, Ferenczy A. Cervical cancer: epidemiology, prevention and the role of human papillomavirus infection. CMAJ. 2001;164:1017-1025.

4. Park SY, Wang HY, Kim SH, Kim GH, Bong SY, Jang HS, et al. Performance of HPV E6/E7 mRNA genotyping test on paired cervical. Biomedical Science Letters. 2016;22:98-106.

5. Goodman A. HPV testing as a screen for cervical cancer. BMJ. 2015;350:h2372.

6. Riley RR, Duensing S, Brake T, Münger K, Lambert PF, Arbeit JM. Dissection of human papillomavirus E6 and E7 function in transgenic mouse models of cervical carcinogenesis. Cancer Res. 2003;63:4862-4871.

7. Shai A, Brake T, Somoza C, Lambert PF. The human papillomavirus $\mathrm{E} 6$ oncogene dysregulates the cell cycle and contributes to cervical carcinogenesis through two independent activities. Cancer Res. 2007;67:1626-1635.

8. Arbeit JM1, Howley PM, Hanahan D. Chronic estrogen-induced cervical and vaginal squamous carcinogenesis in human papillomavirus type 16 transgenic mice. Proc Natl Acad Sci U S A. 1996;93:2930-2935.

9. Elson DA, Riley RR, Lacey A, Thordarson G, Talamantes FJ, Arbeit JM. Sensitivity of the cervical transformation zone to estrogen-induced squamous carcinogenesis. Cancer Res. 2000; 60:1267-1275.

10. Chung SH, Franceschi S, Lambert PF. Estrogen and ER- $\alpha$ : culprits in cervical cancer?. Trends Endocrinol Metab. 2010;21:504-511.

11. Spurgeon ME, Chung SH, Lambert PF. Recurrence of cervical cancer in mice after selective estrogen receptor modulator therapy. Am J Pathol. 2014;184:530-540.

12. Hellberg D. Sex steroids and cervical cancer. Anticancer Res. 2012:32:3045-3054.

13. Girón RA, Montaño LF, Escobar ML, López-Marure R. Dehydroepiandrosterone inhibits the proliferation and induces the death of HPV-positive and HPV-negative cervical cancer cells through an androgen- and estrogen-receptor independent mechanism. FEBS J. 2009;276:5598-5609.

14. den Boon JA, Pyeon D, Wang SS, Horswill M, Schiffman M, Sherman M, et al. Molecular transitions from papillomavirus infection to cervical precancer and cancer: Role of stromal estrogen receptor signaling. Proc Natl Acad Sci U S A. 2015;112: E3255-264.

15. Moodley J. Combined oral contraceptives and cervical cancer. Curr Opin Obstet Gynecol. 2004;16:27-29.

16. Gierisch JM, Coeytaux RR, Urrutia RP, Havrilesky LJ, Moorman PG, Lowery WJ, et al.. Oral contraceptive use and risk of breast, cervical, colorectal, and endometrial cancers: a systematic review. Cancer Epidemiol Biomarkers Prev. 2013;22:1931-1943.

17. Gheit T, Landi S, Gemignani F, Snijders PJ, Vaccarella S, Franceschi S, et al. Development of a sensitive and specific assay combining multiplex PCR and DNA microarray primer extension to detect high-risk mucosal human papillomavirus types. J Clin Microbiol. 2006;44:2025-2031.

18. Kitchener HC, Almonte M, Gilham C, Dowie R, Stoykova B, Sargent A, et al. ARTISTIC: a randomised trial of human papillomavirus (HPV) testing in primary cervical screening. Health 
Technol Assess. 2009;13:1-150, iii-iv.

19. de Sanjose S, Quint WG, Alemany L, Geraets DT, Klaustermeier JE, Lloveras B, et al. Human papillomavirus genotype attribution in invasive cervical cancer: a retrospective cross-sectional worldwide study. The Lancet Oncology. 2010;11, 1048-1056.

20. Hellman K, Lindquist D, Ranhem C, Wilander E, Andersson S. Human papillomavirus, p16(INK4A), and Ki-67 in relation to clinicopathological variables and survival in primary carcinoma of the vagina. Br J Cancer. 2014;110:1561-1570.

21. Paterni I, Granchi C, Katzenellenbogen JA, Minutolo F. Estrogen receptors alpha $(\operatorname{ER} \alpha)$ and beta $(\operatorname{ER} \beta)$ : subtype-selective ligands and clinical potential. Steroids. 2014;90:13-29.

22. Lee HR, Kim TH, Choi KC. Functions and physiological roles of two types of estrogen receptors, $\mathrm{ER} \alpha$ and $\mathrm{ER} \beta$, identified by estrogen receptor knockout mouse. Lab Anim Res. 2012;28: 71-76.

23. Hess RA. Estrogen in the adult male reproductive tract: a review. Reprod Biol Endocrinol. 2003;9:1-52.

24. Hong D, Lu W, Ye F, Hu Y, Xie X. Gene silencing of HPV16 E6/E7 induced by promoter-targeting siRNA in SiHa cells. Br $\mathrm{j}$ Cancer. 2009;101:1798-1804.

25. Benard VB, Watson M, Castle PE, Saraiya M. Cervical carcinoma rates among young females in the United States. Obstet Gynecol. 2012;120:1117-1123.

26. Ferlay J, Shin HR, Bray F, Forman D, Mathers C, Parkin DM. Estimates of worldwide burden of cancer in 2008:GLOBOCAN 2008. IJC. 2010;127:2893-2917. https://doi.org/10.1002/ijc. 25516.

27. World Health Organization (WHO). Comprehensive cervical cancer control: a guide to essential practice. 2nd ed. 2014;9-40. [Internet]. Geneva: World Health Organization; 2018 [cited 2018 Nov 1]. Available from: http://www.who.int/reproductivehealth/publications/cancers/cervical-cancer-guide/en/.

28. LaCour DE, Trimble C. Human papillomavirus in infants: transmission, prevalence, and persistence. J Pediatr Adolesc Gynecol. 2012;25: 93-97.

29. Koshiol J, Lindsay L, Pimenta JM, Poole C, Jenkins D, Smith JS. Persistent human papillomavirus infection and cervical neoplasia: a systematic review and meta-analysis. Am J Epidemiol. 2008;168:123-137.

30. Rao X, Huang X, Zhou Z, Lin X. An improvement of the $2^{\wedge}$ (-delta delta CT) method for quantitative real-time polymerase chain reaction data analysis. Biostat Bioinforma Biomath. 2013;3:71-85.

31. Shen K, Yueng W, Ngan H. Estrogen and progesterone receptors in normal cervix and primary cervical carcinoma. Chin Med J (Engl). 1994;107:648-652.

32. Kumar MM, Davuluri S, Poojar S, Mukherjee G, Bajpai AK, Bafna UD, et al. Role of estrogen receptor alpha in human cervical cancer-associated fibroblasts: a transcriptomic study. Tumour Biol. 2016;37:4409-4420. https://doi.org/10.1007/s13277-0154257-6.

33. Kim G, Cho H, Lee D, Park S, Lee J, Wang HY, et al. Comparison of FFPE historical versus LBP cytological samples for HPV detection and typing in cervical cancer. Exp Mol Pathol. 2017;102:321-326. https://doi.org/ 10.1016/j.yexmp.2017.02.015.
34. Barut MU, Kale A, Kuyumcuoğlu U, Bozkurt M, Ağaçayak E, Özekinci S, et al. Analysis of sensitivity, specificity, and positive and negative predictive values of smear and colposcopy in diagnosis of premalignant and malignant cervical lesions. Med Sci Monit. 2015;21:3860-3867. https://doi.org/10.12659/MSM. 895227.

35. Benevolo M, Vocaturo A, Caraceni D, French D, Rosini S, Zappacosta R, et al. Sensitivity, specificity, and clinical value of human papillomavirus (HPV) E6/E7 mRNA assay as a triage test for cervical cytology and HPV DNA test. J Clin Microbiol. 2011;49:2643-2650. . https://doi.org/10.1128/JCM.02570-10.

36. Radley D, Saah A, Stanley M. Persistent infection with human papillomavirus 16 or 18 is strongly linked with high-grade cervical disease. Hum Vaccin Immunother. 2016;12:768-772. https://doi.org/ 10.1080/21645515.2015.1088616.

37. Ferenczy A, Franco E. Persistent human papillomavirus infection and cervical neoplasia. Lancet Oncol. 2002;3:11-16. https://doi.org/10.1016/S1470-2045(01)00617-9.

38. Park SY, Yoon HS, Bang HE, Kim Y, Choi SK, Ahn SW, et al. Analytical performance of sensitivity and specificity for rapid multiplex high risk human papillomavirus detection kit: HPV ViroCheck. Korean J Clin Lab Sci. 2017;49:446-454. https://doi.org/10.15324/kjcls.2017.49.4.446.

39. Kim IK, Choi HM, Kim MH. Menopausal knowledge and management in peri-menopausal women. J Korean Soc Menopause. 2012;18:124-131. https://doi.org/10.6118/jksm.2012.18.2.124.

40. Lee $\mathrm{KH}$, Che SC. Introduction to partial least square: common criteria and practical considerations. Adv Mater Res. 2013;779-780:1766-1769. https://doi.org/10.4028/www.scientific. net/AMR.779-780.1766.

41. Moore DS, Notz WI, Flinger MA. The basic practice of statistics. 6th ed. New York: W. H. Freeman and company; 2013. p138.

42. Schneider A, Hommel G, Blettner M. Linear regression analysis: part 14 of a series on evaluation of scientific publications. Dtsch Arztebl Int. 2010;107:776-782. https://doi.org/10.3238/ arztebl.2010.0776.

43. Zhai Y, Bommer GT, Feng Y, Wiese AB, Fearon ER, Cho KR. Loss of estrogen receptor 1 enhances cervical cancer invasion. Am J Pathol. 2010;177: 884-895. https://doi.org/10.2353/ ajpath.2010.091166.

44. Roura E, Travier N, Waterboer T, de Sanjosé S, Bosch FX, Pawlita $\mathrm{M}$, et al. The influence of hormonal factors on the risk of developing cervical cancer and pre-cancer: results from the EPIC cohort. PLoS One. 2016;11:e0147029. https://doi.org/10. 1371/journal.pone.0147029.

45. Lau SK, Chu PG, Weiss LM. Immunohistochemical expression of estrogen receptor in pulmonary adenocarcinoma. Appl Immunohistochem Mol Morphol. 2006;14:83-87. https://doi.org/ 10.1097/01.pai.0000168593.35850.9c.

46. Liu S, Semenciw R, Mao Y. Cervical cancer: the increasing incidence of adenocarcinoma and adenosquamous carcinoma in younger women. CMAJ. 2001;164:1151-1152.

47. van der Horst J, Siebers AG, Bulten J, Massuger LF, de Kok IM. Increasing incidence of invasive and in situ cervical adenocarcinoma in the Netherlands during 2004-2013. Cancer Med. 2017;6:416-423. https://doi.org/10.1002/cam4.971. 